\title{
The architecture of the former Carmelite Monastery in the Mali Dorohostai village in Volhynia
}

\author{
Petro Rychkov \\ Department of Conservation of Built Heritage, Faculty of Civil Engineering and Architecture, \\ Lublin University of Technology; \\ Nadbystrzycka St. 40, 20-618 Lublin, Poland; \\ p.a.rychkov@pollub.pl (iD)0000-0003-4559-6111
}

\begin{abstract}
Monasteries of the Roman Catholic order of the Carmelites were well-represented in the historic cities of Volhynia (e.g. Berdychiv, Dubno, Vyshnivets, Kisilin, Lutsk, etc.). One of them was built in the Mali Dorohostai village, which currently is a part of the Mlyniv district in Rivne Oblast of Ukraine. This monastery, built in the mid- $18^{\text {th }}$ century, was closed in the 1830s, and then adapted by the Russian Tsar for the use of Orthodox Church. During the first World War, it was completely destroyed. The architecture of this monastery is almost forgotten in modern historiography. The recently discovered archival drawings from the first half of the $19^{\text {th }}$ century give a good idea of the stylistic and structural characteristics of the no longer existing monastery.
\end{abstract}

Keywords: Volhynia, Mali Dorohostai village, Carmelite Monastery, architecture

\section{Introduction}

There are a lot of still "unread pages" in the architectural history, especially when it comes to little-known documents with architectural drawings. Scattered in diverse archives, these sources sometimes reveal the unexpected, forgotten phenomena of the past - even when they represent only one small piece of paper, yellowed from long lying in the archive shelves. Unknown or at least little-known information may be of great importance. Such unexpected finds in the old archives may help to fill some holes in the background of the history of architecture. Such discoveries are especially important when they describe the unexpected (or unknown) architectural building or element, which has long ceased to exist. One of them is the former Carmelite Monastery in the village of Mali Dorohostai near Mlyniv town in the Rivne Oblast (Fig. 1). 


\section{The history of the Church}

There are not much information about the history of this Church. It is mentioned very briefly in "Geographical dictionary of the Kingdom of Poland" [1], despite the fact that this edition is generally characterized by a sufficiently detailed content. Strangely enough, this Monastery is not even mentioned in the publications of Polish researchers B. J. Wanat [2] and J. Kowalczyk [3], Wołyniak [4] and L. Popek [5] also said about it very few things.

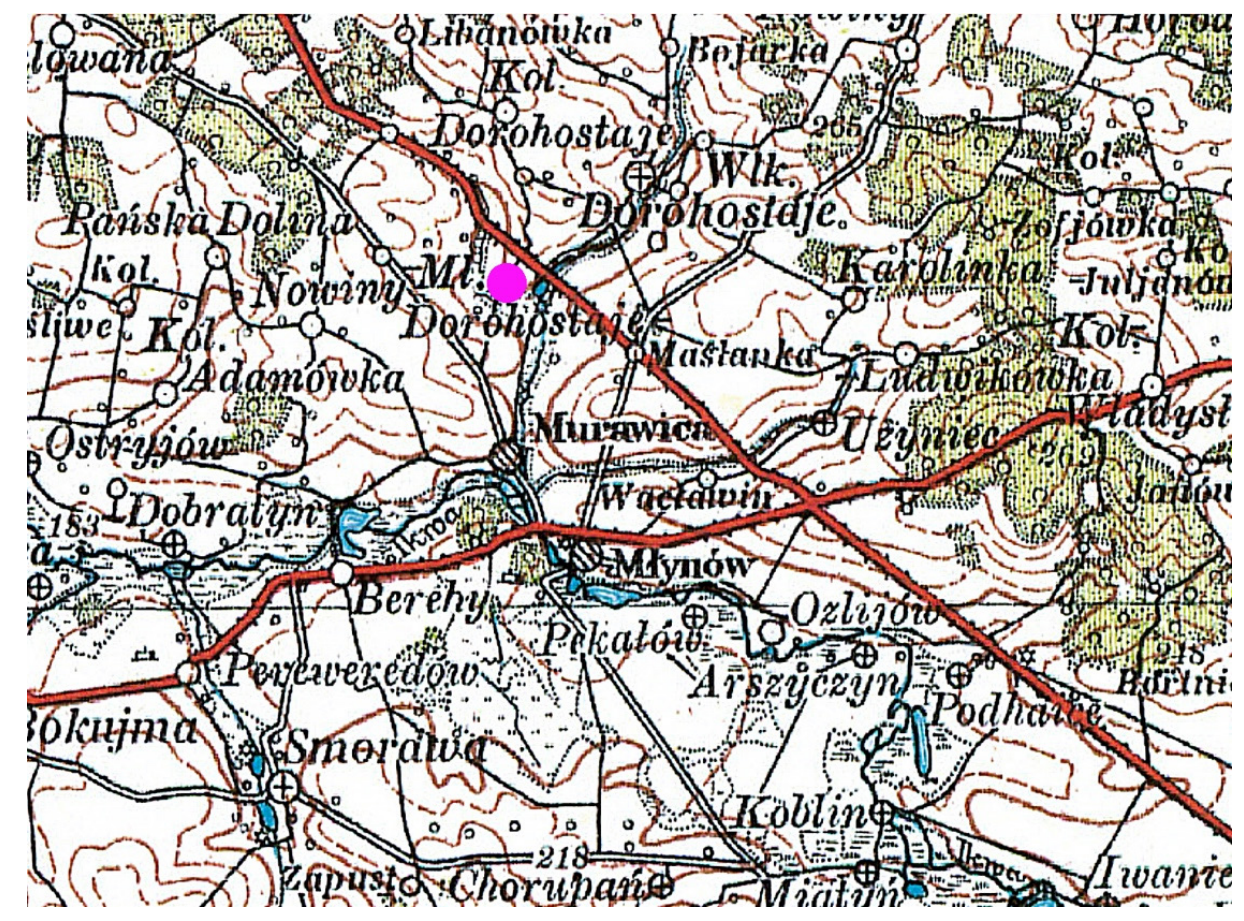

Fig. 1. The location of the Dorohostai village on the geographical map. Source: Wojskowy Instytut Geograficzny. 77-Luck. 1928. Scale: 1:300000

A brief information about the Church was presented at that time also by N. Teodorovych: "The Church of the Intercession of the Blessed Virgin Mary. Rebuilt from the Carmelite Church, founded in the $18^{\text {th }}$ century. Made of stone, rebuilt in 1873. All parts were renewed, with a new iconostasis, and a bell tower above the porch of the Treasury funds (9 000 rubles) and parishioners (2 000 rubles) [...]. In 1887, painted inside and outside" [6].

Interesting facts were also presented in one of the guidebooks to Volhynia. "5 kilometres North from Mlynov are Velyki and Mali Dorohostai, i. e. two villages by the Ikva river; where one-fifth of the 4,000 inhabitants are Czechs. In the $17^{\text {th }}$ century, these estates belonged to Sapieha princely family, and later were divided between the newly arrived Bohemian settlers (colony Maslianka). In the Mali Dorohostai, Jan Sapieha and his wife Constance von Gerburt founded the Carmelite Church on the site of the ancient Arian Church in the early $17^{\text {th }}$ century. It was a solid Baroque building with one nave, completed in 1679, and after abolition in $1832^{1}$,

It concerns repressive actions of the tsarist authorities in Russia about the Catholic Church after the Polish uprising in 1830-31s. 
it was rebuilt into a Russian Orthodox Church. During the First World War, the Church was destroyed and only bare walls without arches remained" [7].

Unfortunately, these days not every resident of this picturesque village is able to say where exactly this temple was. Currently, only a few elderly remember its existence. And there is only one old man, who, on the basis of on the tales of his ancestors, could show us the place, where this Church was standing before WWI.

\section{The survey of archival materials}

Only one paper describing the state of the Church after its takeover from the Carmelite Order was preserved. The document written in Russian is called "The design of the former Carmelites Monastery in Dubno County, in the village of Dorohostai. Copy" [8]. There were four administrative remarks on the side of the text, which specify the circumstances of the creation of this paper. In general, the notes confirmed the intentions of the Russian authorities to undertake drastic repressions against the Roman Catholic Church after the November Uprising of 1830-31.

The earliest note on the margins states: "It was written on January $31^{\text {st }}$ day of 1836 . Measured and charted from the nature by Volhynian diocesan architect K. Mikhailovsky". Below, however, it shows that it is a copy made by a draftsman Domontovich on $22^{\text {nd }}$ February 1840. Another note is the confirmation of the document by the Commission of Projects and Estimates on $31^{\text {st }}$ January 1840 . There are also signatures of the architects from St. Petersburg P. O. Visconti and O. Ruska [9]. The last note made on $5^{\text {th }}$ February 1840 is the approvement of the Council of Communications and Public Buildings. There is also a signature confirming the verification of the compliance of this copy with the original.

Architectural designs on the paper are concise and consist of three images: a plan of the Church together with the line of the surrounding stone walls (Fig. 2) and the main and side facades (Fig. 3). Details of planned changes to the previous architectural style of this Church are not known. Although, as it seems, the main architectural characteristics of this sanctuary remained unchanged.

According to the plan, it was a single-nave church with a cylindrical roof, narthex, and small rectangular altar with two side extensions. There is a reason to believe that these two extensions and the iconostasis were the design proposals to adapt the former Carmelite Church to the needs of the Orthodox Divine Liturgy. For it is uncharacteristic for the Carmelite Church to lack the other buildings within the stonewalls. It seems that according to this project, they had to be dismantled.

The main and side facades are drawn neatly enough in watercolour technique, with three-tier composition scheme of the main facade, representative architectonic articulations - the entrance portal, vertical pilasters, and horizontal profiles of the central gable, and two small symmetrical towers completing the composition of the facade. There are almost no architectural articulations on the side facade, which might be interpreted as the result of the special cleansing of the previous Baroque style of Carmelite Church.

The information given by M. Teodorovych about the bell tower "over the porch" is particularly interesting. It confirms that there was a new annex to the Church by the main entrance. In the $2^{\text {nd }}$ half of the $19^{\text {th }}$ century, it was a fairly common way to make architectural transformation of former Catholic and the Greek-Catholic (Uniate) churches to the architectural canons of the Russian Orthodox Church. After the two Polish uprisings, imperial authorities have strengthened anti-Catholic politics and hence more radical architectural transformations of former Catholic churches and monasteries. 


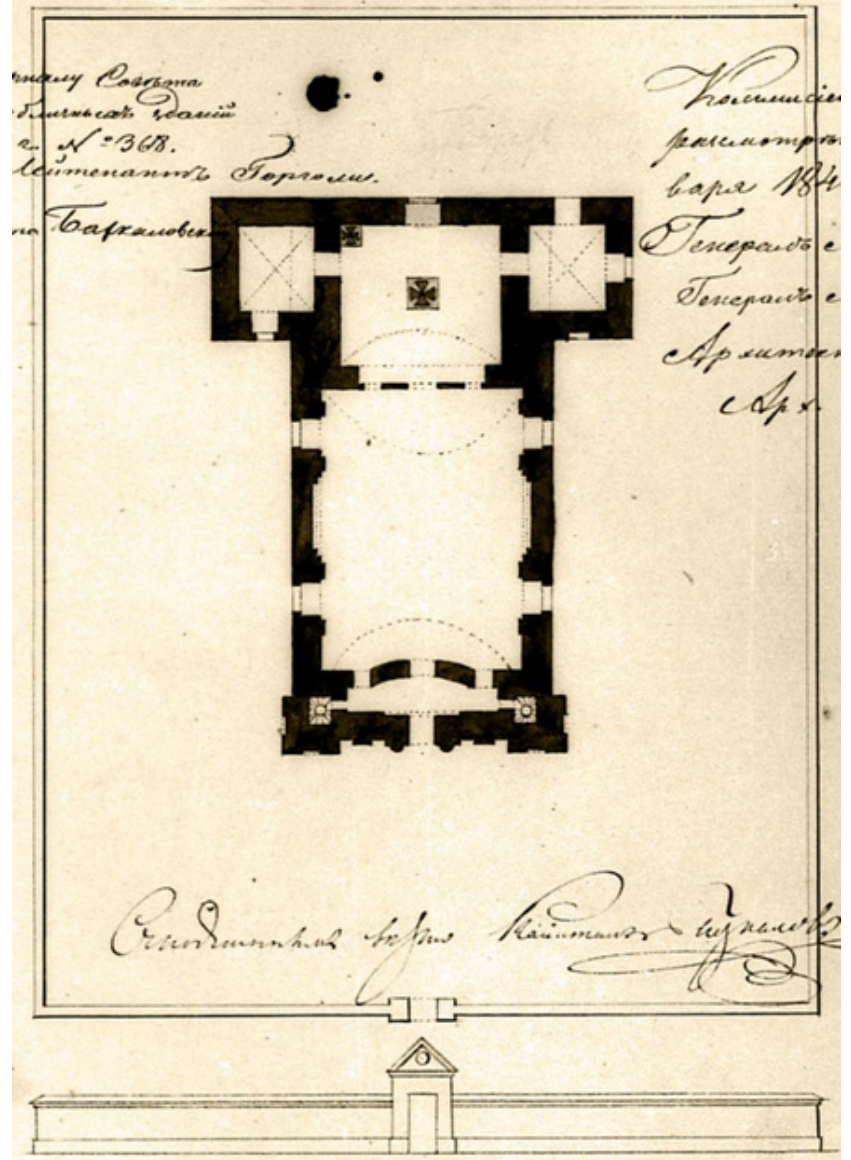

Fig. 2. "The design of the former Carmelites Monastery in Dubno County, in the village of Dorohostai". Fragment 1. Source: RSHA collection

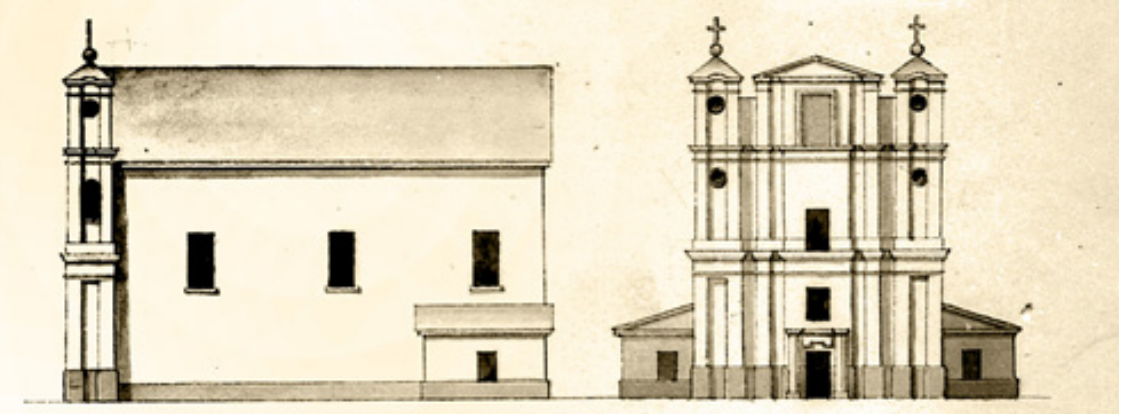

Fig. 3. "The design of the former Carmelites Monastery(...)". Fragment 2. Source: RSHA collection 
A practical approach to the adaptation of the Catholic Church to the Orthodox Liturgy is confirmed by another archival paper entitled "Of the repair of the former Carmelite Church which came into possession of the Orthodox Ministry in the village Dorohostai in Dubno district of Volhynian province" [10].

The temple was destroyed during the First World War and the actual changes in the architectural forms of the temple in the process of its adaptation to the different needs of the Orthodox Church are difficult to judge. Nevertheless, these blueprints can be perceived as the first attempt to adapt the building for the use of Orthodox Church. This is probably the reason why there is not even one residential or auxiliary building indicated on the paper, which certainly existed in the days of the Carmelite Monastery.

\section{Summary}

Undoubtedly, an unknown author of this architectural drawing was facing a hard task. He was to adapt the former Catholic architecture to the different liturgical traditions of the Orthodox Church. However, he had apparently a rather cautious stance on the architectural transformations of the church. A possible reason for his adopted stance could be, firstly, the stylistic conservatism of the former Carmelite Church and, secondly, the implementation of Orthodox architectural forms at that times would be difficult and very costly. At the end of such architectural transformation, the former Catholic Church would become the Orthodox style with only minimal stylistic changes. In 1873, the Church was rebuilt once again, this time fully in accordance with so called the "Russian Revival style". Afterwards, during the WWI this sacral building was completely destroyed. Nevertheless, as its archival pictures show, it remains an interesting example of a Catholic Church in Volhynia, built by the Carmelites for needs of their local Monastery, later adapted for the needs of the Russian Orthodox Church, and finally lost during WWI.

\section{References}

[1] Stownik Geograficzny Królestwa Polskiego. T. II. Warszawa, 1881. p.124.

[2] Wanat B. J. Zakon karmelitów bosych w Polsce. Klasztory karmelitów i karmelitanek bosych 1605-1975. Kraków, 1979.

[3] Kowalczyk J. Światynie póżnobarokowe na kresach. Kościoly i klasztory w diecezjach na Rusi Koronnej. Warszawa, 2006.

[4] Giżycki J.M. (Wołyniak),. Z przeszłości karmelitów na litwie i Rusi. Part 1. Kraków 1918. S.117-118.

[5] Popek L, Świątynie Wotynia. T. 1. Lublin, 1997. p. 209.

[6] Teodorowich N. Istoriko-statistićeskoe opisanie cerkvej i prihodov Volynskoj eparhii. T. II. Poćajev, 1889. S. 647-648.

[7] Orłowicz M. Ilustrowany przewodnik po Wolyniu. Łuck, 1929. S.307-308.

[8] "Plan i fasad sušestwû̂šego Dubenskogo uezda, v sele Dorostaâh uprazdnennogo Karmelitanskogo Monastyrå. Kopiå".Rusian State Historical Archive (RSHA). Fond 1488, inv. 1, file 646, fol.1.

[9] Tymofienko V. Zodći Ukrainy kincâ XVIII - poćâtku XX stolit’. Biografićnyj dowidnyk. Kyiv, 1999. p. 54, p311.

[10] "O remonte pokarmelitanskogo kostela, otdanogo pravoslavnomu vedomstwu v sele Dorostaâh Dubenskogo uezda Volynskoj gubernii,,. RSHA. Fond 797, inv. 10, file 27509. 1840-1842. 
